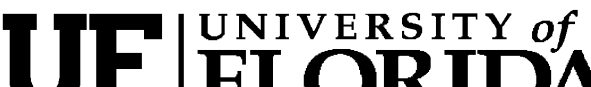 FLORIDA \\ IFAS Extension
}

\section{Pesticide Labeling: Physical or Chemical Hazards ${ }^{1}$}

\section{Frederick M. Fishel ${ }^{2}$}

This document interprets physical or chemical hazards seen on pesticide labels and discusses criteria used in determining the appropriate hazards for the pesticide. Examples of typical statements found on pesticide labels which convey information to the handler of the product are provided.

\section{Introduction}

A pesticide handler for a large commercial agricultural commodity producer unloads a pallet of 5-gallon pesticide containers from a delivery truck with his forklift. The pesticides contain petroleum distillates as part of their inert ingredients. The handler unknowingly places the pallet adjacent to a furnace on an unseasonably cold January morning. Late that evening, a ringing telephone awakens the agricultural establishment's manager and learns from the local emergency response crew that their pesticide storage facility is on fire. Because of environmental considerations with contaminated runoff water from pesticides, the manager is told that the fire will have to burn itself out rather than be put out with conventional methods. Besides the pesticides that were purchased and delivered that morning, more than \$100,000 worth of inventory is destroyed.
Such disasters can be avoided by reviewing the label of the pesticide. The label will address flammability, explosive potential, and other precautions regarding physical or chemical hazards.

\section{Where are the physical or chemical hazards found on the label?}

If a product has specific physical or chemical hazards, they will be listed immediately below the "Hazards to Humans and Domestic Animals" statements and "Environmental Hazards" statements in the "Precautionary Statements" section of the label. It will bear the subheading "Physical or Chemical Hazards."

\section{Labeling for flammable products}

Certain testing criteria determine if a product must bear flammability statements. Testing involves determining the flash point and flame extension of a product. The flash point is the lowest temperature at which a liquid product containing a combustible ingredient that gives off a flammable vapor will ignite. A flame extension test is required for aerosol products. The flame extension test is conducted by holding the aerosol can 6 inches from a flame and

1. This document is PI-97, one of a series of the Pesticide Information Office, Florida Cooperative Extension Service, Institute of Food and Agricultural Sciences, University of Florida. Original publication date February 2006. Visit the EDIS Web Site at http://edis.ifas.ufl.edu.

2. Frederick M. Fishel, associate professor, Agronomy Department, and Director, Pesticide Information Office; Florida Cooperative Extension Service, Institute of Food and Agricultural Sciences, University of Florida, Gainesville, FL 32611.

Use pesticides safely. Read and follow directions on the manufacturer's label.

The Institute of Food and Agricultural Sciences (IFAS) is an Equal Opportunity Institution authorized to provide research, educational information and other services only to individuals and institutions that function with non-discrimination with respect to race, creed, color, religion, age, disability, sex, sexual orientation, marital status, national origin, political opinions or affiliations. U.S. Department of Agriculture, Cooperative Extension Service, University of Florida, IFAS, Florida A. \& M. University Cooperative Extension Program, and Boards of County Commissioners Cooperating. Larry Arrington, Dean 
discharging the product across the flame. The extension of any flame from the flame source (typically a candle) in inches is noted and recorded. Any flame extension more than 18 inches or any flashback of flame to the valve at any degree of valve opening would then dictate the proper labeling of the product as either being flammable or extremely flammable (Table 1). Flashback occurs when the flame is drawn back toward the aerosol can by the stream of propellant. This would indicate an extremely flammable product.

The human hazard signal words CAUTION, WARNING, and DANGER are not used with flammability statements in order to prevent any confusion. For example, if the product is a total release fogger containing a propellent with a flash point at or below $20^{\circ} \mathrm{F}$, the following label statement must be included in the "Physical or Chemical Hazard" section: "This product contains a highly flammable ingredient. It may cause a fire or explosion if not used properly. Follow the Directions for Use on this label very carefully." In addition to the wording, a symbol indicating a highly flammable ingredient will be displayed in this section (Figure 1).

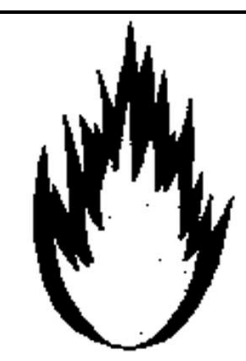

\section{Highly Flammable Ingredient Ingrediente Altamente Inflamable}

\section{Declaration of non-flammability}

Certain products may bear a claim of non-flammability, with terms like "non-flammable" or "non-flammable gas, liquid, etc." Products that bear non-flammability claims do so by meeting the following criteria:

- If a gas or mixture of gases: the product must not ignite when a lighted match is placed against the open cylinder valve.
- If a liquid: the product must have a flash point greater than $350^{\circ} \mathrm{F}$.

The phrases "non-flammable," "non-flammable gas" or "non-flammable liquid," may appear as a sub-statement to the ingredients statement, or on the back or side panel.

\section{Labeling for liquid products used near electrical equipment}

If the product is labeled for use around electrical equipment or electrical outlets and a shock hazard exists, a statement is included in the physical or chemical hazards statement: "Do not apply this product around electrical equipment due to the possibility of shock hazard."

\section{Labeling for explosive potential}

Pesticides that have specific statements for potential explosion hazard include, but are not limited to: sulfur and carbon dust, potassium and sodium nitrate, and potassium chlorate. Each product label will address the specific concern regarding its use pertaining to explosion hazard.

\section{Fumigant hazards}

Some fumigants are highly flammable in the liquid or vapor form. Others, such as those containing the active ingredient sodium or calcium cyanide, have the following statement listed in their physical or chemical hazards: "In the presence of moisture, highly poisonous gas (hydrogen cyanide) is formed."

\section{Miscellaneous physical or chemical hazards}

Some pesticide products have physical or chemical hazards other than flammability or explosive potential. These products may have to address such hazards as oxidizing or reducing capability, reactivity, or corrosiveness.

\section{Additional information}

Fishel, F.M. 2005. Interpreting pesticide label wording. UF/IFAS EDIS Document PI-34. http://edis.ifas.ufl.edu/P1071. 
Table 1. Flammability statements.

\begin{tabular}{||l|l||}
\hline \hline Flash point & Text displayed on label \\
\hline $\begin{array}{l}\text { Flash point at or below } 20^{\circ} \mathrm{F} \text { or if there is a } \\
\text { flashback at any valve opening. }\end{array}$ & $\begin{array}{l}\text { Extremely flammable. Contents under pressure. } \\
\text { Keep away from fire, sparks, and heated surfaces. Do } \\
\text { not puncture or incinerate container. Exposure to } \\
\text { temperatures above } 130^{\circ} \mathrm{F} \text { may cause bursting. }\end{array}$ \\
\hline $\begin{array}{l}\text { Flash point above } 20^{\circ} \mathrm{F} \text { and not over } 80^{\circ} \mathrm{F} \text { or } \\
\text { if the flame extension is more than } 18 \text { inches } \\
\text { long at a distance of } 6 \text { inches from the flame. }\end{array}$ & $\begin{array}{l}\text { Flammable. Contents under pressure. Keep away } \\
\text { from heat, sparks, and open flame. Do not puncture or } \\
\text { incinerate container. Exposure to temperatures } \\
\text { above } 130^{\circ} \mathrm{F} \text { may cause bursting. }\end{array}$ \\
\hline All other pressurized containers. & $\begin{array}{l}\text { Contents under pressure. Do not use or store near } \\
\text { heat or open flame. Do not puncture or incinerate } \\
\text { container. Exposure to temperatures above 130 } \\
\text { may cause bursting. }\end{array}$ \\
\hline At or below $20^{\circ} \mathrm{F}$. & $\begin{array}{l}\text { Extremely flammable. Keep away from fire, sparks, } \\
\text { and heated surfaces. }\end{array}$ \\
\hline Above $20^{\circ}$ and not over $80^{\circ} \mathrm{F}$. & Flammable. Keep away from heat and open flame. \\
\hline Above $80^{\circ} \mathrm{F}$ and not over $150^{\circ} \mathrm{F}$. & $\begin{array}{l}\text { Combustible. Do not use or store near heat or open } \\
\text { flame. }\end{array}$ \\
\hline \hline
\end{tabular}

